Yüzüncü Y1l Üniversitesi
Tarim Bilimleri Dergisi
(YYU Journal of Agricultural Science)

\title{
Geçmişten Günümüze Genetik ve Kromozom Mühendisliği Çalışmalarının Sürdürülebilir Tarım ve Bitki Islahına Katkısı
}

\author{
Sevim D. Kara ÖZTÜRK ${ }^{1}$, Bilge Ş. YILDIRIM² ${ }^{2}$ Hümeyra YILDIZ ${ }^{3}$, Ahmet L. TEK*4 \\ 1,2,3,4Niğde Ömer Halisdemir Üniversitesi, Ayhan Şahenk Tarım Bilimleri ve Teknolojileri Fakültesi, Tarımsal \\ Genetik Mühendisliği Bölümü, 51240, Niğde \\ ${ }^{1}$ https://orcid.org/0000-0001-7522-0575 2https://orcid.org/0000-0001-6593-4312 ${ }^{3}$ https://orcid.org/0000-0002-7791-6100 \\ ${ }^{4}$ https://orcid.org/0000-0002-3292-5142 \\ *Sorumlu yazar e-posta: altek2@gmail.com
}

\section{Makale Bilgileri}

Geliş: 30.09 .2020

Kabul: 03.02.2020

Online yayınlanma 30.03.2021

DOI: $10.29133 /$ yyutbd.787094

\section{Anahtar kelimeler}

Biyoteknoloji,

Bitki 1slahı,

Genetik mühendisliği,

Kromozom mühendisliği,

Sürdürülebilir tarım.
Öz: 2050 yılında nüfusun 9.2 milyara ulaşacağı ve dünya genelinde eşit ve insani temel ihtiyaçlara olan taleplerin karşılanması gerektiği öngörülmektedir. Günümüze kadar, tarımsal üretimin arttırılmasına yönelik çeşitli çalışmalar gerçekleştirilmiştir. Bununla birlikte birim alandan daha yüksek verim alınmasını sağlayan yeni teknoloji ve yöntemlerin geliştirilip bitki islah programlarına entegre edilmesi gerekmektedir. Bu entegrasyon sayesinde hem sürdürülebilir tarım anlayışına uyumsuz aşırı girdi ve mekanizasyon kullanımı azaltılabilecek hem de bitki biyolojisi, evrimi, genom yapısı anlaşılarak tarımda verimlilik arttırılabilecektir. Ayrıca genetik çeşitlilikten yararlanılması, model bitkilerden sağlanan verilerin bitki ıslah programlarına adapte edilmesi, yetim bitkilerin genetik kaynak potansiyelinin kullanılmasına yönelik çalışmalar yeni genotiplerin eldesine katkı sağlayacaktır. Bugüne kadar gen transformasyonu, DNA dizilemesi, genom haritalaması ve genom düzenleme gibi modern teknolojiler bitkilerde genom yapısının anlaşılmasında etkin rol oynamıştır. FISH, GISH, telomer aracılığıyla kromozom kesimi, minikromozomlar, organizmalar arası sintenik kromozomal lokuslarının saptanması, tekrarlayan DNA elementlerinin keşfi ve yapısal CENH3 proteininin kullanımı gibi çok sayıda kromozom mühendisliği yöntemleri de tarımsal gelişmede itici güç oluşturacaktır. Temel bilimlerdeki ilerlemelerden faydalanan tarımsal araştırmalar uzun vadede istenilen amaca ulaşmayı destekleyecek ve gelecekte kromozom mühendisliği yöntemleri özelinde tarımsal üretimin artırılmasına katkı sağlayacaktır. Tüm bunlara ek olarak, bu derleme makalesinde bir araya getirilen güncel ve hızlı gelişen disiplinler arası tematik çalışmalar ve aynı zamanda tarım, islah ve genetik disiplinlerinden sentezlenen perspektiflerin, bu alanlarda çalışan araştırmacılara yönlendirici bir tartışma platformu sunması hedeflenmiştir.

\section{Contribution of Genetic and Chromosome Engineering Studies from Past to Present to Sustainable Agriculture and Plant Breeding}

\section{Article Info}

Received: 30.09.2020

Accepted: 03.02.2020

Online Published 30.03.2021
Abstract: It is predicted that by 2050 the population will reach 9.2 billion and the demands for equal and basic needs must be met worldwide. Until today, various studies have been carried out to increase agricultural production. However, new technologies and methods that ensure higher 
DOI: 10.29133/yyutbd.787094

\section{Keywords}

Biotechnology, Chromosome engineering, Genetic engineering, Plant breeding Sustainable agriculture yields per unit area should be developed and integrated into plant breeding programs. While contradictory practices to sustainable agriculture should still be reduced, productivity in agriculture can be increased by understanding plant biology, evolution, and genome structure. In addition, efficient use of genetic diversity, adaptation of knowledge from model plants to breeding programs, and the genetic resource potential of orphan plants will contribute to the development of new genotypes. So far, modern technologies such as gene transformation, DNA sequencing, genome mapping and genome editing have played an active role in understanding the genome structure in plants. Numerous chromosome engineering methods such as FISH, GISH, chromosome truncation via telomeres, mini chromosomes, detection of syntenic chromosomal loci between organisms, discovery of repetitive DNA elements and the use of structural CENH3 protein will also be a driving force in agricultural development. Agricultural research, benefiting from the advances in basic sciences, will support achieving the desired goal in the long term. Potentially, chromosome engineering methods contribute to the increase of agricultural production in the future. In this review article, we aim to create a discussion platform for researchers by providing unique perspectives synthesized from agriculture, breeding and genetics and bringing together the current and rapidly developing interdisciplinary thematic studies.

\section{Giriş}

Dünya nüfusunun her geçen gün artış göstermesi ile birlikte 2050 yılında 9.2 milyara ulaşacağı ve meydana gelen bu artışa paralel olarak gıda, yem ve lif gibi temel ihtiyaçlara olan talebin neredeyse iki katına çıkacağı tahmin edilmektedir (Ronald, 2014). Tarımsal üretimle birlikte, gıda, giyinme, barınma, ilaç ve yakıt gibi temel yaşam unsurları doğrudan ve dolaylı olarak sağlanmaktadır. Ancak, kentleşme, çölleşme, doğal dengenin bozulması ve çevresel stres etmenlerinin etkisiyle kullanılabilir tarım arazileri azalmaktadır. Dünya genelinin, ekilebilir arazi, su kaynaklarındaki azalmalar, daha az tarımsal üretime eğilim gibi çeșitli çevresel ve sosyal zorluklarla karșı karșıya kalacağı öngörülmektedir (Varshney ve May, 2012). Gelişen teknoloji ve artan bilgi birikimiyle bitki yapılarının anlaşılması, verimli çeşitlerin geliştirilmesi ve bitki genetik çeşitliliğinin muhafazası tarımsal üretimde devamlılığın sağlanmasında önemli bir rol oynamaktadır (Gross ve ark., 2014). Bu durumda tarımsal üretimi arttırmak ancak birim alandan daha yüksek verim sağlayacak yeni teknolojiler ile gerçekleştirilebilir.

Tarımsal üretimin devamlılığı klasik ıslah yöntemleri ile başlamış olup günümüzde ise modern teknolojilerle devam etmektedir. Son yıllarda kromozom ve genetik mühendisliği yöntemleri aracılığıyla geliştirilebilecek bitki ıslah programlarının, hem sürdürülebilir tarımın devamlılığını hem de bitkilerin genom yapısının daha iyi anlaşılmasını sağlayarak tarımsal üretime katkıda bulunması hedeflenmektedir.

\section{Sürdürülebilirlik Bağlamında Tarımsal Üretim}

Tarımsal sürdürülebilirlik, gelecek nesillerin kendi ihtiyaçlarını karşılama yeteneğinden ödün vermeden günümüzün ihtiyaçlarını karşılamamız gerektiği ilkesine dayanmaktadır (Brodt ve ark., 2011). Tarım; gıda, lif, inşaat malzemeleri, biyokütle ve enerji gibi hammaddeler sağladığı gibi, çevre dostu sürdürülebilir bir ekosistemin oluşmasına da katkıda bulunabilir (Paoletti ve ark., 2011). Bununla birlikte, sürdürülebilir tarım ve gıda için etkili yöntemlerin kullanılmasıyla; ekosistem dengesinin sağlanması, doğal kaynaklarının korunması ve verimliliğinin arttırılması, insanlığın gereksinim duyduğu geçim kaynaklarının iyileştirilmesi beklenmektedir (FAO, 2020).

Yeni teknolojiler, mekanizasyon, artan kimyasal kullanımı, uzmanlaşma gibi gıda ve lif üretimini en üst düzeye çıkarmayı ve gıda fiyatlarını düşürmeyi hedefleyen politikaların tarım üzerinde birçok olumlu etkisi bulunmaktadır (Brodt ve ark., 2011). Buna rağmen, toprak erozyonu ve değişen iklim koşullarının etkileri ile meydana gelen organik madde kaybı, nüfus artışı ile doğru orantılı olarak tarım sistemi üzerindeki bask1 sonucu meydana gelen toprak verimliliğinde azalma, 
tarımsal ekosistemin direncindeki bozulmalara neden olmakta ve bu durum tarımda sürdürülebilirliği de tehdit etmektedir (Paoletti ve ark., 2011).

Tarımsal sürdürülebilirlik, hem tüm modern biyoteknolojik yaklaşımlar kullanılarak genotiplerin iyileştirilmesine hem de ekolojik ve tarımsal yönetim, manipülasyon ve yeniden düzenlemelerin daha iyi anlaşılmasına odaklanılmasını önermektedir (Pretty, 2008). Bu nedenle her organizmanın kendi doğası gereği genetik açıdan eşsiz olduğu düşünüldüğünde yeni çeşitlerin eldesinde doğal genetik kaynaklardan yararlanılması gerektiği açıktır. Bu durum karşısında; artan dünya nüfusu, ekilebilir alanların azalması ve kentleşme ile birlikte meydana gelen gıda üretim sorunlarını gidermek için geliştirilen çalışmalarda bitki genetik çeşitliliği önem kazanmaktadır (Govindaraj ve ark., 2015).

\section{Genetik Çeşitlilik ve Tarımsal Üretimdeki Önemi}

Genetik çeşitlilik, bir türün sahip olduğu değişken popülasyonlar arasındaki genetik varyasyonu ifade etmektedir (Ramanatha Rao ve Hodgkin, 2002). Genetik çeşitlilik ve dağılımının tespiti ve bunların analizi, bitkilerdeki çeşitli biyolojik olayların moleküler temelinin anlaşılmasına, bu çeşitliliğin korunmasına, ilgili bitki türlerinin taksonomisi, kökeni ve evrimi hakkındaki bilgi birikiminin arttırılmasına katkı sağlamaktadır (Agarwal ve ark., 2008).

Farklı bitki genotipleri önemli tarımsal karakterler bakımından varyasyonlar göstermektedir. Bitkilerde genetik varyasyonun zenginliği, bitki sslah çalışmaları ile yeni çeşitlerin geliştirilmesinde ileri düzeyde seçenekler sunmaktadır (Govindaraj ve ark., 2015). Temel biyoteknoloji çalışmalarındaki ilerlemelerin en etkin özelliklerinden biri genom ölçeğindeki varyasyonun türler düzeyinde karakterize edilmesidir (Cook ve Varshney, 2010). Ayrıca, moleküler teknikler aracılığıyla gerçekleştirilen filogenetik ve evrimsel çalışmalar, tür içi ve türler arasındaki genetik varyasyonun dağılımı ve kapsamı hakkında detaylı bilgiler sunmaktadır (Mondini ve ark., 2009).

Günümüz ıslah stratejileriyle kültür bitkileri ve yabani akrabalarından karakterize edilen genetik çeşitlilik kullanılarak ileri dönemlerdeki sslah çalışmalarına katkı sağlayacağı düşünülmektedir (Fears, 2007). Bu bağlamda ileri dönemlerde yapılacak ıslah çalışmalarında genetik çeşitlilikten daha fazla faydalanılması, arzu edilen karaktere uygun ebeveyn seçiminde genetik kaynaklar önem göstermektedir.

Geçmişten günümüze farklı ıslah yöntemlerin kullanılmasıyla istenilen karakterlere sahip bitki çeşitlerinin geliştirilerek tarımsal üretimde verim artışı sağlanmıştır. Tarımsal üretimde meydana gelen verim artışı temelde sulama ve gübreleme gibi tarımsal uygulamaların iyileştirilmesi ve bitki çeşitlerinin genetik potansiyellerinin arttırılması yoluyla gerçekleştirilmektedir (Acquaah, 2012). Gelecek yıllarda artan nüfusa bağlı olarak sulama kaynakları, yeni ortaya çıkan patojenler ve zararlılar, durağan verimlerden kaynaklı sorunların çözümünde özellikle bitki genetiği ve genetik mühendisliği gibi alanların öncü rol oynayacağı ileri sürülmektedir (Cook ve Varshney, 2010). Sonuç olarak artan nüfusun gıda taleplerinin karşılanabilmesi, tarımsal ürün verimliliği ve tarımsal sürdürülebilirliğin iyileştirilmesine katkıda bulunmak için genetik çeşitlilikten yararlanılması ve yeni bitki ıslah tekniklerinin geliştirilmesine ihtiyaç duyulmaktadır (Lusser ve ark., 2012). Bu ihtiyacın karşılanması için tarımsal üretim yapısının ve tiplerinin net bir şekilde ifade edilmesi gerekmektedir.

\section{Tarımsal Üretimin Tipleri}

İlerleyen teknolojik gelişmelerle birlikte artan bilgi birikiminin, tarımsal üretimi geliştirmek için hangi safhalarda ve basamaklarda hedeflenebileceğinin ayrıntılı irdelenmesi gereklidir. Bu amaçla bu derleme makalesine özgü olarak tarımsal üretim tipleri, tarımda verimlilik ve sürdürülebilirlik açısından kullanılan teknolojik yöntemler, hedef kitlesi ve amaçları doğrultusunda üç genel tipe ayırarak karşılaştırmalı olarak analiz edilecektir (Şekil 1).

Tip A olarak adlandırılan modern tarımda, yüksek verimli ve kaliteli bitki çeşitlerinin üretimi hedeflenmektedir. Bu üretim tipinde, klasik sslah ve genetik mühendisliği teknikleriyle geliştirilen çeşitler kullanılmaktadır. Geleneksel tarım olarak ifade edilen Tip B üretim modelinde ise, modern tarıma göre daha küçük ölçekli aile işletmeleri gerçekleştirilmektedir. Bu üretim modelinde, tip A üretim modelinden farklı olarak sadece klasik ıslah yöntemleri kullanılmaktadır. Tip B modeli ya da geleneksel tarım döneminde verim ve kaliteli ürün artışının en somut örneği, yeşil devrim olarak 
adlandırılan Norman Borlaug tarafından yüksek verimli buğday ve çeltik çeşitlerinin geliştirilmesi sonucunda görülmüştür. Birim alanda daha yüksek verime ulaşılması hedeflenen bu dönemde; tarımsal üretimde belirli bir artış sağlanmış olmasına rağmen, sulamaya ve monokültüre dayalı üretim toprağa ve çevreye zarar verebilecek tarımsal uygulama ve kimyasalların kullanımı sürdürülebilir tarım çalışmaları kapsamında negatif etkiler sunmaktadır (Aguilar-Rivera ve ark., 2019). Romantik tarım ise teknolojinin yok denecek kadar az kullanıldığı daha çok hobi amaçlı ferdi bazlı üretimin yapıldığı Tip $\mathrm{C}$ modeli olarak adlandırılan diğer bir üretim tipidir.

Doğrudan veya dolaylı amaçlarla kullanılan bitkilerin genom özelliklerinin aydınlatılması biyoteknoloji araçlarına adapte edilebilirliği ve uygunluğu noktasında farklılıklarının tespit edilmesi tarımsal üretimi sınırlayan negatif etkilerin giderilmesinde önem taşımaktadır. Bu amaç doğrultusunda biyolojik bilgi sağlama potansiyeli yüksek model bitkiler, hâlihazırda kullanılan kültür bitkileri ve genetik kaynak potansiyeli olabilecek yetim bitkiler genom çalışmalarında etkinliğin arttırılabilmesi için önemlidir.

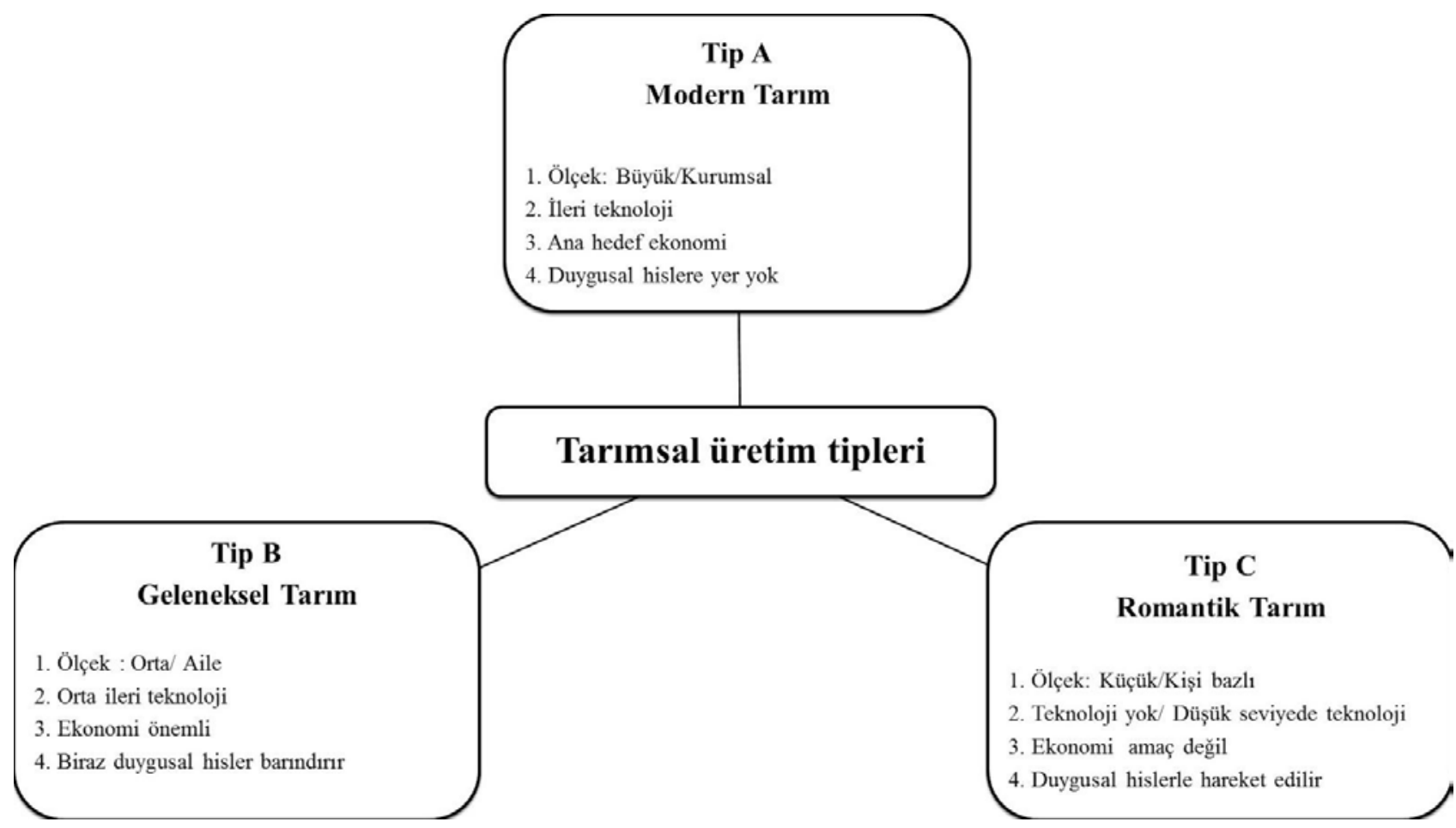

Şekil 1. Tarımsal üretimin genel tipleri. Tip A üretim modeli modern tarım, Tip B modeli geleneksel tarım ve Tip C modeli ise romantik tarım hakkında genel özellikleri bir çerçeve halinde sunmaktadir.

\section{Model Bitkiler - Kültür Bitkileri - Yetim Bitkiler}

Dünya da model bitki olarak kabul edilen Arabidopsis, bitki gelişimi, fizyolojisi, hücre biyolojisi ve genetik alanlarındaki temel araştırmaların uygulandığı bitki türüdür (Chang ve ark., 2016). Yeni nesil DNA dizileme yöntemlerinin 2000'li y1llarda gelişmesine paralel olarak nispeten küçük genom büyüklüğüne sahip Arabidopsis genomunun dizilenmesi üzerine diğer model bitki türlerinde de çalışmalar gerçekleştirilmeye başlamıştır (Armstead ve ark., 2009). Model bitkiler vasıtasıyla saptanan veriler, karşılaştırmalı genomik, sinteni, QTL haritalama gibi yöntemlerde kullanılarak agronomik açıdan değerli bitkilerin genom yapısının aydınlatılmasında ön bilgiler sunmaktadir.

Kültür bitkileri üzerinde insanlık tarihi boyunca seleksiyon ve farklı melezleme tekniklerinden başlayarak çok sayıda ıslah yöntemleri uygulanmıştır. Bu sayede arzu edilen özellikler bakımından çeşit geliştirilerek tarımsal üretimde verim, kalite artışı ve adaptasyon kabiliyeti yüksek ürün eldesi sağlanabilmiştir. Ancak belli başlı türlere eğilim, yıllar içerisinde mevcut genetik kaynaklarda azalma 
ve birçok türün ihmal edilmesi sonucunu doğurmuştur. Bununla birlikte dünyanın temel gıda talebini karşılamak için tarımsal açıdan önemli özelliklerin altında yatan genlerin keşfedilmesi gerekmektedir. Kültür bitki türlerinin bitki 1slah yöntemleri vasıtasıyla geliştirilmesinde gerekli genetik kaynaklara ihtiyaç duyulmaktadır.

Yetim bitkiler ise, yerel düzeyde büyük önem taşımasına rağmen, büyük fon kuruluşları tarafından yatırım almayan, küresel ölçekte sınırlı pazara sahip, genetik ve biyoinformatik çalışmaların az olduğu ihmal edilmiş bitkiler olarak tanımlanmaktadır. (Naylor ve ark., 2006; Armstead ve ark., 2009; Ribaut ve Ragot, 2019). Yetim bitkiler, küresel gıda ve beslenme güvenliğinde önemli bir rol oynamaktadır. İklim değişikliği altında sürdürülebilir gıda sistemlerine katkıda bulunma potansiyeli mevcuttur (Mabhaudhi ve ark., 2019). Yetim bitki türleri düşük verimliliklerine rağmen, yüksek adaptasyona sahiptir. Buna karşılık genetik, tarımsal ve ekonomik özellikleri bakımından çeşitlilik göstermektedir (Naylor ve ark., 2006). Yetim bitkilerin genetik yapısı hakkında araştırmalar yetersiz olduğu için bu bitkiler hakkında çok az bilgi mevcuttur. Yetim bitkiler üzerinde araştırmalar arttıkça bu bitkilerden elde edilen veriler, iyi karakterize edilmiş bir model bitki türüyle karşıllaştırmalı genomik ve biyoinformatik gibi yöntemler aracılığıyla ilişkilendirilebilir ve daha hızlı, etkin çeşit geliştirme çabalarına katkıda bulunabilir (Armstead ve ark., 2009; Ribaut ve Ragot, 2019).

\section{Modern Bitki Islahına Geçiş ve Genetik Mühendisliği}

Bitki 1slahı, üreticilerin ve tüketicilerin ihtiyaçlarına göre bitki çeşitlerin geliştirilmesi, üstün genotipe sahip bitkilerin oluşturulması ve seçilmesi için gerekli yöntemleri sunmaktadır (Moose ve Mumm, 2008). Geçmişten günümüze bilim ve teknolojinin ilerlemesine paralel olarak çok sayıda islah yöntemi kullanılmaktadır ve bilgi birikimi arttıkça hâlen yeni yöntemler geliştirilmektedir (Şekil 2). Bunlar içerisinde en temel klasik bitki sslah yöntemleri seleksiyon ve melezlemedir. Ancak klasik bitki ıslah çalışmalarında kullanılan yöntemlerde bilinen bazı sınırlamalar mevcuttur. Süregelen zaman boyunca mevcut sınırlamaların ortadan kaldırılması için bitki ıslahçıları yeni yöntem arayışlarına girmiştir ve bitki genetik mühendisliğinin sağladığı yeni yöntemlere olan ihtiyaç artmıştır.

Bitki genetik mühendisliği çalışmaları Mendel tarafından gerçekleştirilen araştırmalarla başlamış olup günümüzde hâlen daha yeni teknolojilerle gelişimini sürdürmektedir. Gelişen teknoloji ile birlikte sağlanan bilgiler tarımsal üretimde istenilen karakterler bakımından gerekli bitki sslah çalışmalarının ilerlemesini sağlamıştır. Genetik teknolojilerinin hızlı gelişimi ve benimsenmesi, araştırmacıların genom biyolojisi, heterozis ve karmaşık agronomik özelliklerin kalıtım derecesi ile ilgili temel soruları ele almalarını sağlamaktadır (Varshney ve May, 2012). Ayrıca tüm genom dizilemesi genomu oluşturan elementler açısından ayrıntılı bir resim sunmaktadır (Saraswathy ve Ramalingam, 2011).

Bitkilerde ilk olarak Sanger dizileme yöntemi ile 2000 yılında A. thaliana'nın tüm genom dizilemesinin yapılmasının ardından tüm genom shotgun (Whole Genome Shotgun) dizilemesi kullanılarak 2005 yılında çeltik genom dizilemesi tamamlanmıştır. Dizileme bu birinci nesil tekniklerle kalmayıp, çok sayıda yeni ikinci nesil dizileme teknikleri (Illumina, Roche, SOLiD vb.) geliştirilmiştir. Dizileme tekniklerinin ilerlemesine bağlı olarak dizileme maliyetinin azalması ile birlikte yüksek çözünürlüklü daha uzun dizi okuma uzunlukları sayesinde model ve kültür bitkilerine ek olarak yetim bitkilerinin de dizilenmesi sağlanmıştır (Fleury ve ark., 2012). Böylece yetim bitkilerin genom dinamikleri hakkında daha detaylı bilgiler kazanılmıştır. Daha yakın dönemlerde ise tek molekül DNA kullanımına dayalı üçüncü nesil dizileme teknikleri olan, Helicos Biosciences (Harris ve ark., 2008), Pacific Bioscience (Eid ve ark., 2009) ve Oxford Nanopore yöntemleri kullanılmaya başlanmıştır. Üçüncü nesil dizileme teknolojilerinin diğer yeni nesil dizileme teknolojilerine göre en büyük avantajı uzun DNA moleküllerinin dizilenebilme potansiyelini sağlayarak genom üzerindeki boşlukların tamamlanmasını sağlamasıdır (Fleury ve ark., 2012). Daha uzun okumalar ile tekrar dizilerinin etkisinden dolayı meydana gelen kromozom parçacıklarını birleştirme zorlukları atlatılabilecektir. Tek molekül dizileme ve fiziksel haritalama teknolojilerindeki bu son gelişmeler, bitki türlerinin kromozom ölçeğinde yüksek çözünürlükte birleştirilmesine öncü olmuştur (Michael ve Vanburen, 2020). 


\begin{tabular}{|l|}
\hline Klasik Bitki Islahı \\
\hline Seleksiyon \\
\hline Melezleme \\
\hline Poliploidi \\
\hline Mutasyon \\
\hline
\end{tabular}

\begin{tabular}{|l|}
\hline Biyoteknolojik Yöntemler \\
\hline Moleküler Markörler \\
\hline DNA Dizileme \\
\hline
\end{tabular}

Genetik Haritalama

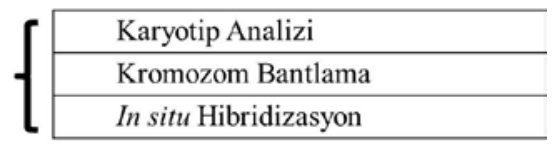

$\int$\begin{tabular}{l}
\hline Telomer Kesimi \\
\hline Minikromozomlar \\
\hline B Kromozomlar1
\end{tabular}

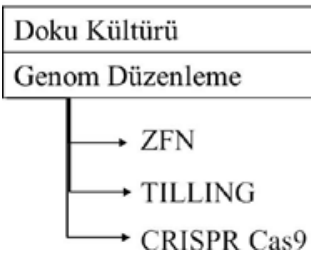

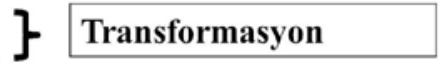

Şekil 2. Bitki ıslah yöntemlerinin genel akışı. Moleküler markörler, DNA dizileme yöntemleri, kromozom karyotip analizi, kromozom bantlama ve in situ hibridizasyon teknikleri genetik haritalamada kullanılan araçlardır. Biyoteknolojik yöntemlerde yer alan gen transferi amacıyla kullanılan vektörlere ek olarak, telomer kesimi, minikromozomlar ve B kromozomları da gen transferi (transformasyon) amaciyla vektör olarak kullanılabilecek potansiyel araçlardır. ZFN, TILLING, CRISPR/Cas9 ve CENH3 katkılı genom eliminasyonu ve doku kültürü çalışmaları haploid bitki üretiminde kullanılabilen yeni teknolojik araçlardır.

\section{Kromozom Çalışmalarının Tarımsal Üretime Katkıları}

Bitki 1slah çalışmaları, klasik yöntemlerle başlamış olup modern biyoteknolojik tekniklerle daha da ileri seviyeye taşınmıştır. Ancak bu çalışmaların kendi içerisinde bir takım zorlukları ve riskleri mevcuttur. Geliştirilebilecek yeni teknikler ile bu sorunların üstesinden gelinmesi hedeflenmektedir. Örneğin ökaryotik bir genomda tekrarlayan DNA dizileri genomun yaklaşı \%90'lık bir kısmını meydana getirmektedir (Charlesworth ve ark., 1994; Heslop-Harrison ve Schmidt, 2012; Hidalgo ve ark., 2017; Mehrotra ve Goyal, 2014). Tekrar elementlerinin genom içerisinde yoğunluk ve dağılımı dizileme işleminden sonra genomun yeniden yapılandırılmasında (genome assembly) zorluklar ortaya çıkarmaktadır. $\mathrm{Bu}$ nedenle genetik haritalamadan ziyade kromozomlar üzerinde tekrarlayan DNA elementlerinin yerlerinin tespitini kolaylaştıran fiziksel haritalama yöntemlerine ihtiyaç duyulmaktadır.

Fiziksel haritalama oluşturabilmek için Southern hibridizasyonu, PCR, Restriksiyon enzimleri ile kesim, Floresan in situ hibridizasyon (FISH) ve Genomik in situ hibridizasyon (GISH) gibi moleküler teknikler kullanılmaktadır. Bu teknikler ile kromozom ölçeğinde yüksek çözünürlüklü genom ayrıştırması ve kromozom karyotip haritası mümkündür (Saraswathy ve Ramalingam, 2011). Kromozomların boyutlarına ve sentromer bölgelerine göre düzenlenmesine karyotipleme adı verilmektedir. Brassicaceae türlerinin karyotip evriminin anlaşılmasında ve kromozom temelli filogenetik haritasının oluşturulmasında, Triticum aestivum türünün standart karyotipinin oluşturulması gibi çok sayıda çalışmada kullanılan C-, Q-, NOR-, G- bantlama ve FISH, GISH gibi teknikler entegre edilerek yüksek çözünürlüklü fiziksel haritalar oluşturulabilmektedir (Gill ve ark., 1991; Mandakova ve Lysak, 2008). 
Özellikle FISH tekniği, tekrarlayan DNA elementlerinin kromozomlar üzerinde yerlerinin tespitinde yol gösterici olmakta ve bir takım kolaylık sağlamaktadır. Ayrıca, bu teknik sayesinde genom dizilemesi sırasında tekrar dizilerinin yarattığı zorluğun üstesinden de gelinebilmektedir (Kato ve ark., 2005; Tek, 2013). Tekrarlayan DNA elementlerinin tespiti bitki genomunun anlaşılmasında, fenotipik analizlerde, gen transferinde kullanılabilir (Biscotti ve ark., 2015; Heslop-Harrison ve Schmidt, 2012; Schmidt ve Heslop-Harrison, 1998). Örneğin iPBS-Retrotranspozon markör sistemi kullanılarak Fritillaria imperialis L. (Terslale) genotiplerinde genetik varyasyon tespit edilmiş olup bu veriler gelecekte yapılacak ıslah çalışmalarında uygun ebeveyn seçimi için ön bilgi oluşturabilecektir (Koçak ve ark., 2020). Ayrıca, Fabaceae familyasında Ty1/copia elementleri (Galasso ve ark., 1997), Musa acumirata (Muz) telomerik tekrar elementleri (Hribova ve ark., 2010), Solanum bulbocastanum (patates) sentromerik ve perisentromerik tekrarlar1 (Tek ve ark., 2005; Tek ve Jiang 2004), Glycine max (soya) satellit ve retrotranspozonları (Tek ve ark., 2010) gibi çok sayıda ökaryotik genomda tekrar elementlerinin kromozomal lokalizasyonları farklı tekniklerle saptanmıştır.

Kromozom analizlerinin bir diğer katkısı ise iki ayrı türün birbirlerine olan yakınlık ve uzaklıklarının ve poliploidi durumlarında atasal kromozomların tespiti açısından önemlidir. Bu durum poliploid türlerin bitki sslah çalışmalarında ilerlemeler sağlayabilmektedir. Poliploid türlerde genlerin nasıl evrimleştiğini anlamak için genomların kökeni, tarihi ve araştırılan gen ailesinin yapısı bilinmelidir (Faris ve ark., 2001). Bitki genomları, değişken sayıda ploidi içerir ve heterozigotluk seviyelerinde farklılık gösterir (Michael ve Vanburen, 2020). Bitki türlerinin büyük çoğunluğu poliploid yapıya sahip olduğundan, genom organizasyonunun ayrıntılarının keşfinde ve genomlar arası benzerlik ve farklılıkların belirlenmesinde GISH tekniğinden yararlanılmaktadır (Shamim ve Armstrong, 2019). Güncel literatür incelendiğinde; allopoliploid Brassica juncea (Shamim ve Armstrong, 2019), Medicago sativa (Falistocco, 2020) gibi çok sayıda bitki türünde GISH tekniği kullanılarak genom yapılarının aydınlatılması ve karyotiplerinin oluşturulması sağlanmıştır.

Genom dizileme teknolojileri geliştikçe, yukarıda ifade edilen sitogenetik araçlar genom fonksiyonunun araştırılmasında ve kromozom organizasyonlarının tespitinde büyük roller üstleneceklerdir (Kato ve ark., 2005). Dizileme teknolojileri aracılığıyla genom dizilemesinden elde edilen çıtılar, temel bilimlerde bilgi birikimini artırarak, bitki genomunun özelliklerini ayrıntılı açıklamayı mümkün kılmaktadır (Fears, 2007; Varshney ve May, 2012). Bu sayede bitki 1slahı için genetik kaynak potansiyeli olan bitki türlerinin ileri düzey genom bilgisi elde edilecektir. Ayrıca yapılan analizlerin sonuçları, genom yapısı ve dinamiklerinin hakkında önemli bilgiler sağlayabilir ve türler arasındaki filogenetik ilişkileri anlamamıza katkıda bulunabilir (Faris ve ark., 2001).

Modern biyoteknolojik tekniklerin sağladığı tüm bu avantajların yanı sıra; ilerlemelere bağlı olarak bazı risklerde mevcuttur. Örneğin transformasyon sonrası bitkilerin seleksiyonu için seçilebilir markör genlerinin kullanılması çevresel kaygı ve insan sağlı̆̆ bakımından risk oluşturmasıdır. Ayrıca gen transferi yöntemlerinin çoklu genlerin transferindeki sorunları ve gen susturması gibi dezavantajları bulunmaktadır (Dhar ve ark., 2011). Bu nedenle bilim adamları yeni arayış içine girmiştir. Temel kromozom çalışmalarından elde edilen bilgiler, minikromozomlar veya bitki yapay kromozomları bu arayışın çözüm alternatifi olarak ortaya çıkmaktadır. Bu bağlamda, seçici markör genleri olmadan transformasyon çalışmaları için bitki yapay kromozom teknolojisi bir firsat sunmaktadır (Barampuram ve Zhang, 2011). Minikromozomlar, ökaryotik kromozomların işlevsel yapılarını ortaya çıkarmak için kullanılan araçlardır (Murata, 2014). Yapay kromozomlar (minikromozomlar) birkaç gen kümesinin tek bir bağımsız kromozomda birleştirmesini sağlayarak kararlı ve kalıtsal bir platform sağlayabilir (Cody ve ark., 2015). Bitki yapay kromozom teknolojisinin en somut örneği kromozom temelli vektör inşasında kendini göstermektedir. Minikromozomların vektör olarak kullanılmasının sağlayacağı bazı avantajlar aşağıda ifade edilmiştir (Dhar ve ark., 2011; Yu ve ark., 2016). Bu avantajlar: 1) Minikromozomların küçük olması, 2) arzu edilen genlerin tek bir kromozomda birleştirilmesi, 3) melezleme (crossing) ile transferinin kolay olması, 4) mayoz ve mitoz bölünme sırasında sabit olması ve nesilden nesile aktarılabilmesi, 5) genom dizileme yöntemleri sayesinde minikromozomlar üzerindeki genlerin silinmesi, eklenmesi ve düzenlenmesidir. Kromozom temelli vektör olarak gen transferinde kullanılan kromozomların telomer aracılığıyla kesilmesi sonucu oluşturulan minikromozomlar, Arabidopsis ve mısırda B kromozomlarının keşfi yeni çeşit geliştirilmesinde potansiyel göstermektedir (Yu ve ark., 2007; Birchler ve ark., 2008; Houben ve ark., 2011; Murata, 2014). B kromozomları bazı bitki türlerinde doğal olarak bulunabildiği gibi kromozom mühendisliği teknikleri ile sonradan genoma dahil edilebilir. Bu tip kromozomların temel genlerden 
yoksun olmaları, telomer aracılığıyla B kromozomlarının kesilmesiyle meydana getirilen minikromozomların oluşturulması için bir avantaj sunmaktadır (Dhar ve ark., 2011; Cody ve ark., 2015). Kromozom mühendisliği yöntemlerinde ilerlemeler ve genom düzenleme yöntemlerinin minikromozomların oluşturulmasında katkılarına bağlı olarak yeni çeşitlerin geliştirilmesinde kullanılması beklenmektedir (Murata, 2014; Cody ve ark., 2015). Bu sayede genetik mühendisliğinin yukarıda ifade edilen sınırlamalarını çözümlemek için geliştirilen kromozom mühendisliği yöntemleri genetik çeşitlilik sağlayarak sürdürülebilir tarım için gerekli kaynakları oluşturabilir. Böylece artan nüfusa karşı gida güvenliğinin teminatı sağlanabilir.

\section{Genom Düzenlemenin Kromozom Mühendisliği Perspektifinde Katkıları}

Temel bilimler alanında yeni bir teknolojik gelişme olan genom düzenleme yöntemleri, biyolojik araştırmalara katkı sağlamaktadır (Vats ve ark., 2019). Bu yöntemlerin, birden çok hedefi aynı anda düzenleme potansiyeli bulunmaktadır (Vats ve ark., 2019). ZFN, TILLING ve CRISPR/Cas9 genom düzenleme yöntemlerinin kullanımı tarımsal üretimin gelişiminde yeni bir döneme geçilmesini sağlamıştır. CRISPR/Cas9 teknolojisi yüksek etkinlik göstermesi ve diğer düzenleme yöntemlerine göre basit olması nedeniyle bitki genom düzenleme yöntemleri içerisinde en geçerli yaklaşımdır ve bitki ıslahının geliştirilmesinde yeni olanaklar sunmaktadır (Stajič ve ark., 2019).

Double (katlanmış) haploid yaklaşımlara dayanan ıslah çalışmalarında \%100 homozigot saf hatların elde edilmesi bitki ıslah programlarının hızlandırılmasını ve güvenli sonuçlar alınmasını sağlamasından dolayı son zamanlarda yeni bir araç konumuna ulaşmıştır (Tek ve ark., 2015; Cerit ve ark., 2016). Haploid bitki türlerinin eldesinde in vitro ve in vivo olmak üzere çok sayıda yöntem kullanılmaktadır. Ancak bu yöntemlerin kullanımının genotipe bağlı olması, haploid üretim için gerekli olan indüzer (inducer) hatların türe özgü olması, doku kültürü çalışmalarında türe spesifik ortamların oluşturulması gibi sınırlamalar mevcuttur. Bu nedenle genom eliminasyonunun sentromer vasıtasıyla kazandırıldığı haploid üretim model ümitvar bir yaklaşım olarak kullanılan yeni bir yöntemdir (Tek ve ark., 2015). Kromozomların temel yapısal parçası olan sentromer, hücre bölünmesi sırasında kromozomların doğru ve eksiksiz dağılımı ve yavru hücrelere aktarımı için gereklidir. Sentromer bölgesi sentromere özgü DNA tekrar dizilerinden ve aktif sentromerlerin temel bileşeni olan sentromere özgü histon H3 (CENH3) proteininden oluşmaktadır (Houben ve Schubert, 2003; Wang ve ark., 2009; Lermontova ve Schubert 2013). Aktif sentromer bölgesinde yer alan nükleozomlar, standart histon $\mathrm{H} 3$ proteinin bir varyant1 olan $\mathrm{CENH} 3$ proteininin standart histon $\mathrm{H} 3$ ile yer değiştirmesiyle tanımlanır (Houben ve Schubert, 2003). CENH3 homologları, insan (Palmer ve ark., 1991), maya (Stoler ve ark.,1995), Drosophila (Henikoff ve ark., 2000), Arabidopsis (Talbert ve ark., 2002), çeltik (Nagaki ve ark., 2004), misır (Zhong ve ark., 2002), soya (Tek ve ark., 2010), arpa (Sanei ve ark., 2011), muz (Muiruri ve ark., 2017) gibi çok sayıda farklı türde karakterize edilmiştir.

İlk olarak Ravi ve Chan, (2010) Arabidopsis thaliana model türünde CENH3 proteini üzerinde modifikasyonlar yaparak genom eliminasyonunu sağlamışlardır. CRISPR/Cas9 sistemi ve CenH3 geninin bir arada kullanımıyla Brassica oleracea türünde CENH3 haploid indüzer hatlar Agrobacterium ve protoplast transformasyon sistemleri aracılığıyla aktarılmıştır (Stajič ve ark., 2019). Benzer şekilde sorgum bitkisinde CenH3 geninde CRISPR/Cas9 aracılı̆̆ıyla genom düzenlenmesi Agrobacterium aracılığıyla transformasyon sisteminde uygulanmak üzere geliştirilmiştir (Che ve ark., 2018). CRISPR/Cas9 aracılığıla CenH3 geninde delesyon sonucu yaratılan mutasyon ile A. thaliana türünde haploid indükleyici hatlar elde edilmiştir (Kuppu ve ark., 2020). Özetle homozigot saf hatların elde edilmesi için gereken zaman, yüksek iş gücü ve maliyet haploid bitki üretimini sınırlamaktadır (Kurtar ve ark., 2020). Bununla birlikte; CENH3 evrimsel olarak korunduğu için böylesi bir kromatin bileşeni üzerinde yapılan modifikasyonlardan elde edilen çıktılar, diğer haploid üretim yöntemlerine göre evrensel sonuçlar oluşturabilecektir ve haploid üretiminde türe özgü sınırlamaları ortadan kaldırabilecek potansiyeli sunacaktır.

\section{Sinteni: Genlerin Kromozom Boyunca Benzer Sıralanışı}

Sinteni terimi genetikte aynı kromozomda iki veya daha fazla lokus varlığını belirtmek için kullanılmaktadır (McCouch, 2001). Sinteni vasitasiyla elde edilen genetik bilgiler hastalıklara 
dayanıklılık, biyotik ve abiyotik strese tolerans gibi önemli özellikleri sağlayan genlerin ortologlarını ya da homologlarının saptanmasında kullanılmaktadır. Örneğin Solanaceae familyası içerisinde yer alan patates ve domates bitkilerinin temel kromozom sayıları 12'dir $(\mathrm{n}=12)$. Yapılan karşıllaştırmalı haritalama çalışması sırasında her iki türün 9 kromozomunun lokus sırasının birbiriyle aynı olduğu ancak geri kalan 3 kromozom üzerinde perisentromerik bölgede inversiyonlar olduğu açığa çıkarılmıştır (Bonierbale ve ark., 1988). Benzer şekilde Poaceae familyası içerisinde yer alan çeltik, cin darı, mısır, sorgum ve Triticeae türlerinin sinteni haritası çıkarılmıştır (Bennetzen ve Chen, 2008). $\mathrm{Bu}$ çalışmaya göre, gen sıralaması ve telomer bölgesinin büyük ölçüde korunduğu, kromozom sayısının ise türler arasında değişkenlik gösterdiği saptanmıştır. Ayrıca sinteni haritalaması ile önemli özellikleri kodlayan genlerin ortologlarının yerleri de gösterilmiştir. Tespit edilen bu bilgiler 1şığında büyük genoma sahip kültür bitkilerinin harita tabanlı klonlanmasını kolaylaştırmak için nispeten daha küçük genoma sahip model bitkiler kullanılmaktadır (Bennetzen ve Chen, 2008). Brassica oleracea ve Arabidopsis karşılaştırmalı haritalama çalışmaları sonucunda sinteni bölgeleri tespit edilmiş ve Brassica oleracea mevcut genlerinin ortologlarının Arabidopsis üzerinde oldukça korunmuş olduğu bildirilmiştir (O'Neill ve Bancroft, 2000). Ek olarak, Arabidopsis ve domates karşılaştırmalı dizileme çalışması ile meyve şeklini kontrol eden geninin tespiti yapılmıştır (Ku ve ark., 2000).

\section{Sonuç}

Bilimsel çalışmalarda sürekliliğin sağlanması için temel ve uygulamalı araştırmaların bir arada yürütülmesi gerekmektedir (Clark, 2007). Uygulamalı ve temel bilimler arasında uçurumun olmadığının anlaşılması ve koordineli olarak birbirine bağlı olduğunun benimsenmesine ihtiyaç vardır. Hazırlanan 1slah programları temel bilimsel bilgilerden yararlanılarak tasarlandığında elde edilen sonuçlar uzun vadede daha yüksek başarılar sağlayabilecektir. Ayrıca tarımsal ürünlere olan talep bu yüzyılın ilk yarısına kadar ikiye katlanacaktır (Varshney ve May, 2012). Artan nüfusunun aksine tarım alanlarının daha fazla genişletilemeyecek durumda olması üretim alanlarının genişletilmesini sınırladığından, birim alanda tarımsal ürünlerin miktar ve kalitesinin artmasına yönelik çalışmalarla taleplerin desteklenmesi ve yenilikçi yollar bulunması gerekmektedir (Cody ve ark., 2015). Örneğin, Arabidopsis gibi model türlerden sağlanan bilgiler ve deneysel yaklaşımlar kullanılarak daha az karakterize edilmiş yetim bitki türlerinde çalışmalar mümkün kılınabilir ve ilerleyen teknolojilerle birlikte aday genler yönünden bitki sslahında katkıda bulunabilir (Cook ve Varshney, 2010). Tarımın ihtiyaç duyduğu teknoloji değişiminin kaynağı temel bilimlerden gelmektedir. Temel bilimlerden saptanan veriler kullanılarak uygulamalı tarım bilimleri desteklenmeli ve bitki sslah çalışmaları daha etkin hâle getirilmelidir. Böylece tarımsal üretimde verimin arttırılması sağlanmalıdır.

Artan gıda ihtiyaç talebinin karşılanması için yeni teknolojilerle birlikte tarımın daima bir arada ilerlemesi gerekmektedir. Tarımda verimliliği artırıp, yüksek kalitede ürün eldesi sağlanırken, aynı zamanda çevre ve insan sağlığını gözetecek şekilde yapılan çalışmalar, klasik bitki 1slah yöntemleri yanı sıra, genetik ve kromozom mühendisliği yöntemleri aracılığıyla gerçekleştirilebilmektedir. Bugüne kadar yapılan klasik ıslah çalışmaları ve tarımsal uygulamalar (gübreleme vs.) yoluyla ürünlerde verim ve kaliteyi arttırmak amacıyla kullanılan iki stratejidir. Ancak genetik ve kromozom mühendisliği, küresel gıda güvenliğini sağlamak için başka stratejiler sunmaktadır (Cody ve ark., 2015). Örneğin Sanger, Illumina, Oxford Nanopore dizileme yöntemleri, doku kültürü, tek gen aktarımını sağlayan transformasyon teknikleri, QTL, bağlantı haritalaması, moleküler markör teknikleri, CRISPR/Cas9 gibi genom düzenleme ve kromozom mühendisliği kapsamında yer alan yöntemlerin kullanımı bitki ıslah çalışmalarında çeşit geliştirilmesi için ön bilgiler sunmuştur ve sunmaya devam etmektedir. Genetik ve kromozom bilimi uygulamalı tarım bilimlerinin ilerlemesi için önemlidir. Genom haritalama çalışmaları kullanılan yöntemlere ek olarak, satellit tekrarlar, transpozon elementleri ve 5S, 45S gibi ribozomal DNA dizilerinin kromozomlar üzerinde lokalizasyonları FISH ve C-bantlama gibi bantlama teknikleri ile gösterilmiştir. Ayrıca, poliploid türlerde GISH metodu ile kromozom karyotip analizi sağlanarak farklı bir bakış açısı sunulmuştur. Gelecekte, tüm genom dizilemeleri için hâlen büyük zorluk getiren tekrar dizilerinin sitogenetik yöntemler ve biyoinformatik çalışmalar ile anlaşılması, minikromozomlar veya B kromozomlarının gen transferinde bir vektör olarak kullanılabilmesi, CENH3 üzerinde yaratılan mutasyon haploid üretiminde gelişmeler tarımsal üretimde çeşit geliştirilmesinde ve genetik çeşitliliğin sağlanmasında ciddi bir potansiyel oluşturacaktır. 


\section{Teşekkür}

ALT, SDKÖ, BŞY ve HY TÜBİTAK (118O670; 118Z589), COST CA16212 - Impact of Nuclear Domains On Gene Expression and Plant Traits projeleri tarafindan desteklenmektedir. SDKÖ, BŞY ve HY YÖK 100/2000 programı tarafından desteklenmektedir. Bitki Kromozom Laboratuvarındaki çalışmalarımız Ayhan Şahenk Vakfı tarafından desteklenmektedir.

\section{Kaynakça}

Acquaah, G. (2009). Principles of Plant Genetics and Breeding. John Wiley \& Sons. 1-22.

Agarwal, M., Shrivastava, N., \& Padh, H. (2008). Advances in molecular marker techniques and their applications in plant sciences. Plant Cell Reports, 27(4), 617-631.

Aguilar-Rivera, N., Michel-Cuello, C., \& Cárdenas-González, J. F. (2019). Green Revolution and Sustainable Development. In W. Leal Filho (Ed.), Encyclopedia of Sustainability in Higher Education (pp. 833-850). Springer International Publishing.

Armstead, I., Huang, L., Ravagnani, A., Robson, P., \& Ougham, H. (2009). Bioinformatics in the orphan crops. Briefings in Bioinformatics, 10(6), 645-653.

Barampuram, S., \& Zhang, Z. J. (2011). Recent advances in plant transformation. Methods in Molecular Biology (Clifton, N.J.), 701, 1-35.

Bennetzen, J. L., \& Chen, M. (2008). Grass genomic synteny 1lluminates plant genome function and evolution. Rice, 1(2), 109-118.

Birchler, J. A., Yu, W., \& Han, F. (2008). Plant engineered minichromosomes and artificial chromosome platforms. Cytogenetic and Genome Research, 120(3-4), 228-232.

Biscotti, M. A., Olmo, E., \& Heslop-Harrison, J. S. P. (2015). Repetitive DNA in eukaryotic genomes. Chromosome Research: An International Journal on the Molecular, Supramolecular and Evolutionary Aspects of Chromosome Biology, 23(3), 415-420.

Bonierbale, M. W., Plaisted, R. L., \& Tanksley, S. D. (1988). RFLP maps based on a common set of clones reveal modes of chromosomal evolution in potato and tomato. Genetics, 120(4), 10951103.

Brodt, S., Six, J., Feenstra, G., Ingels, C. \& Campbell, D. (2011) Sustainable agriculture. Nature education knowledge 3(10),1. https://www.nature.com/scitable/knowledge/library/sustainableagriculture-23562787/. Erişim tarihi: 12.05.2020.

Cerit, İ., Cömertpay, G., Oyucu, R., Çakir, B., Hatipoğlu, R., \& Özkan, H. (2016). Melez mısır 1slahında ın-vivo katlanmış haploid tekniğinde kullanılan farklı inducer genotiplerin haploid indirgeme oranların belirlenmesi. Tarla Bitkileri Merkez Araş. Enstitüsü Dergisi, 25(1), 52-57.

Chang, C., Bowman, J. L., \& Meyerowitz, E. M. (2016). Field guide to plant model systems. Cell, 167(2), 325-339.

Charlesworth, B., Sniegowski, P., \& Stephan, W. (1994). The evolutionary dynamics of repetitive DNA in eukaryotes. Nature, 371(6494), 215-220.

Che, P., Anand, A., Wu, E., Sander, J. D., Simon, M. K., Zhu, W., Sigmund, A. L., Zastrow-Hayes, G., Miller, M., Liu, D., Lawit, S. J., Zhao, Z.-Y., Albertsen, M. C., \& Jones, T. J. (2018). Developing a flexible, high-efficiency Agrobacterium-mediated sorghum transformation system with broad application. Plant Biotechnology Journal, 16(7), 1388-1395.

Clark, W. C. (2007). Sustainability science: A room of its own. Proceedings of the National Academy of Sciences, 104(6), 1737-1738.

Cody, J. P., Swyers, N. C., McCaw, M. E., Graham, N. D., Zhao, C., \& Birchler, J. A. (2015). Minichromosomes: Vectors for Crop Improvement. Agronomy, 5(3), 309-321.

Cook, D. R., \& Varshney, R. K. (2010). From genome studies to agricultural biotechnology: Closing the gap between basic plant science and applied agriculture. Current Opinion in Plant Biology, 13(2), 115-118.

Dhar, M. K., Kaul, S., \& Kour, J. (2011). Towards the development of better crops by genetic transformation using engineered plant chromosomes. Plant Cell Reports, 30(5), 799-806.

Eid, J., Fehr, A., Gray, J., Luong, K., Lyle, J., Otto, G., Peluso, P., Rank, D., Baybayan, P., Bettman, B., Bibillo, A., Bjornson, K., Chaudhuri, B., Christians, F., Cicero, R., Clark, S., Dalal, R., 
deWinter, A., Dixon, J., Turner, S. (2009). Real-Time DNA sequencing from single polymerase molecules. Science, 323(5910), 133-138.

Falistocco, E. (2020). Insight into the chromosome structure of the cultivated tetraploid alfalfa (Medicago sativa subsp. Sativa L.) by a combined use of GISH and FISH techniques. Plants, 9(4), 542.

Faris, J., Sirikhachornkit, A., Haselkorn, R., Gill, B., \& Gornicki, P. (2001). Chromosome mapping and phylogenetic analysis of the Cytosolic Acetyl-CoA Carboxylase Loci in wheat. Molecular Biology and Evolution, 18(9), 1720-1733.

FAO (2020). Food and Agriculture organization. http://www.fao.org/sustainability/en/. Erişim tarihi: 15.04.2020.

Fears, R. (2007). Genomics and genetic resources for food and agriculture. Commission on genetic resources for food and agriculture. http://www.fao.org/3/a-k0174e.pdf. Erişim tarihi: 12.06.2020.

Fleury, D., Baumann, U., \& Langridge, P. (2012). Plant genome sequencing: Models for developing synteny maps and association mapping. In A. Altman \& P. M. Hasegawa (Ed.), Plant Biotechnology and Agriculture (pp. 83-97). Academic Press.

Galasso, I., Harrison, G. E., Pignone, D., Brandes, A., \& Heslop-harrison, J. S. (1997). The distribution and organization of Ty1-copia-like retrotransposable elements in the genome of Vigna unguiculata (L.) Walp. (Cowpea) and its Relatives. Annals of Botany, 80(3), 327-333.

Gill, B. S., Friebe, B., \& Endo, T. R. (1991). Standard karyotype and nomenclature system for description of chromosome bands and structural aberrations in wheat (Triticum aestivum). Genome, 34(5), 830-839.

Govindaraj, M., Vetriventhan, M., \& Srinivasan, M. (2015). Importance of genetic diversity assessment in crop plants and its recent advances: An overview of its analytical perspectives. Genetics Research International, 2015, 431487.

Gross, B. L., Kellogg, E. A., \& Miller, A. J. (2014). Speaking of food: Connecting basic and applied plant science. American Journal of Botany, 101(10), 1597-1600.

Harris, T. D., Buzby, P. R., Babcock, H., Beer, E., Bowers, J., Braslavsky, I., Causey, M., Colonell, J., Dimeo, J., Efcavitch, J. W., Giladi, E., Gill, J., Healy, J., Jarosz, M., Lapen, D., Moulton, K., Quake, S. R., Steinmann, K., Thayer, E., Xie, Z. (2008). Single-molecule DNA sequencing of a viral genome. Science (New York, N.Y.), 320(5872), 106-109.

Henikoff, S., Ahmad, K., Platero, J. S., \& van Steensel, B. (2000). Heterochromatic deposition of centromeric histone H3-like proteins. Proceedings of the National Academy of Sciences of the United States of America, 97(2), 716-721.

Heslop Harrison, J. (Pat), \& Schmidt, T. (2012). Plant nuclear genome composition. In ELS. American Cancer Society.

Hidalgo, O., Pellicer, J., Christenhusz, M., Schneider, H., Leitch, A. R., \& Leitch, I. J. (2017). Is there an upper limit to genome size? Trends in Plant Science, 22(7), 567-573.

Houben, A., \& Schubert, I. (2003). DNA and proteins of plant centromeres. Current Opinion in Plant Biology, 6(6), 554-560.

Houben, A., Nasuda, S., \& Endo, T. R. (2011). Plant B chromosomes. Methods in Molecular Biology (Clifton, N.J.), 701, 97-111.

Hribová, E., Neumann, P., Matsumoto, T., Roux, N., Macas, J., \& Dolezel, J. (2010). Repetitive part of the banana (Musa acuminata) genome investigated by low-depth 454 sequencing. BMC Plant Biology, 10, 204.

Kato, A., Vega, J. M., Han, F., Lamb, J. C., \& Birchler, J. A. (2005). Advances in plant chromosome identification and cytogenetic techniques. Current Opinion in Plant Biology, 8(2), 148-154.

Koçak, M., Karataş, M. D., Alp, Ş., Baloch, F., \& Yildiz, M. (2020). Van Gölü havzasından toplanan Terslale (Fritillaria imperialis L.) genotiplerinde genetik farklılı̆ın iPBS retrotranspozon markırları ile belirlenmesi. Yüzüncü Yll Üniversitesi Tarım Bilimleri Dergisi, 30(2), 398-406.

Kurtar, E. S., Seymen, M., \& Kal, Ü. (2020). An overview of doubled haploid plant production in Cucurbita species. Yüzüncü Yıl Üniversitesi Tarım Bilimleri Dergisi, 30(3), 510-520.

Ku, H.-M., Vision, T., Liu, J., \& Tanksley, S. D. (2000). Comparing sequenced segments of the tomato and Arabidopsis genomes: Large-scale duplication followed by selective gene loss creates a network of synteny. Proceedings of the National Ac. of Sciences, 97(16), 9121-9126. 
Kuppu, S., Ron, M., Marimuthu, M. P. A., Li, G., Huddleson, A., Siddeek, M. H., Terry, J., Buchner, R., Shabek, N., Comai, L., \& Britt, A. B. (2020). A variety of changes, including CRISPR/Cas9-mediated deletions, in CENH3 lead to haploid induction on outcrossing. Plant Biotechnology Journal.

Lermontova, I., \& Schubert, I. (2013). CENH3 for Establishing and Maintaining Centromeres. In J. Jiang \& J. A. Birchler (Eds). Plant Centromere Biology (pp. 67-82). John Wiley \& Sons, Ltd.

Lusser, M., Parisi, C., Plan, D., \& Rodríguez-Cerezo, E. (2012). Deployment of new biotechnologies in plant breeding. Nature Biotechnology, 30(3), 231-239.

Mabhaudhi, T., Chimonyo, V. G. P., Hlahla, S., Massawe, F., Mayes, S., Nhamo, L., \& Modi, A. T. (2019). Prospects of orphan crops in climate change. Planta, 250(3), 695-708.

Mandáková, T., \& Lysak, M. A. (2008). Chromosomal phylogeny and karyotype evolution in x=7 crucifer species (Brassicaceae). The Plant Cell, 20(10), 2559-2570.

McCouch, S. R. (2001). Genomics and synteny. Plant Physiology, 125(1), 152-155.

Mehrotra, S., \& Goyal, V. (2014). Repetitive sequences in plant nuclear DNA: Types, distribution, evolution and function. Genomics, Proteomics \& Bioinformatics, 12(4), 164-171.

Michael, T. P., \& Van Buren, R. (2020). Building near-complete plant genomes. Current Opinion in Plant Biology, 54, 26-33.

Mondini, L., Noorani, A., \& Pagnotta, M. A. (2009). Assessing plant genetic diversity by molecular tools. Diversity, 1(1), 19-35.

Moose, S. P., \& Mumm, R. H. (2008). Molecular plant breeding as the Foundation for 21st Century crop 1mprovement. Plant Physiology, 147(3), 969-977.

Muiruri, K. S., Britt, A., Amugune, N. O., Nguu, E. K., Chan, S., \& Tripathi, L. (2017). Expressed centromere specific histone 3 (CENH3) variants in cultivated triploid and wild diploid bananas (Musa spp.). Frontiers in Plant Science, 8, 1034.

Murata, M. (2014). Minichromosomes and artificial chromosomes in arabidopsis. Chromosome Research, 22(2), 167-178.

Nagaki, K., Cheng, Z., Ouyang, S., Talbert, P. B., Kim, M., Jones, K. M., Henikoff, S., Buell, C. R., \& Jiang, J. (2004). Sequencing of a rice centromere uncovers active genes. Nature Genetics, 36(2), 138-145.

Naylor, R. L., Falcon, W. P., Goodman, R. M., Jahn, M. M., Sengooba, T., Tefera, H., \& Nelson, R. J. (2004). Biotechnology in the developing world: A case for increased investments in orphan crops. Food Policy, 29(1), 15-44.

O’Neill, C. M., \& Bancroft, I. (2000). Comparative physical mapping of segments of the genome of Brassica oleracea var. Alboglabra that are homoeologous to sequenced regions of chromosomes 4 and 5 of Arabidopsis thaliana. The Plant Journal: For Cell and Molecular Biology, 23(2), 233-243.

Paoletti, M. G., Gomiero, T., \& Pimentel, D. (2011). Introduction to the Special Issue: Towards A More Sustainable Agriculture. Critical Reviews in Plant Sciences, 30(1-2), 2-5.

Palmer, D. K., O’Day, K., Trong, H. L., Charbonneau, H., \& Margolis, R. L. (1991). Purification of the centromere-specific protein CENP-A and demonstration that it is a distinctive histone. Proceedings of the National Academy of Sciences of the United States of America, 88(9), 3734-3738.

Pretty, J. (2008). Agricultural sustainability: Concepts, principles and evidence. Philosophical Transactions of the Royal Society B: Biological Sciences, 363(1491), 447-465.

Ramanatha Rao, V., \& Hodgkin, T. (2002). Genetic diversity and conservation and utilization of plant genetic resources. Plant Cell, Tissue and Organ Culture, 68(1), 1-19.

Ravi, M., \& Chan, S. W. L. (2010). Haploid plants produced by centromere-mediated genome elimination. Nature, 464(7288), 615-618.

Ribaut, J.-M., \& Ragot, M. (2019). Modernising breeding for orphan crops: Tools, methodologies, and beyond. Planta, 250(3), 971-977.

Ronald, P. (2011). Plant genetics, sustainable agriculture and global food security. Genetics, 188(1), $11-20$.

Ronald, P. C. (2014). Lab to Farm: Applying research on plant genetics and genomics to crop improvement. PLoS Biology, 12(6), e1001878. 
Sanei, M., Pickering, R., Kumke, K., Nasuda, S., \& Houben, A. (2011). Loss of centromeric histone H3 (CENH3) from centromeres precedes uniparental chromosome elimination in interspecific barley hybrids. Proceedings of the National Academy of Sciences, 108(33), E498-E505.

Saraswathy, N., \& Ramalingam, P. (2011). Genome mapping. In N. Saraswathy \& P. Ramalingam (Eds.), Concepts and Techniques in Genomics and Proteomics, pp. 77-93.

Schmidt, T., \& Heslop-Harrison, J. S. (1998). Genomes, genes and junk: The large-scale organization of plant chromosomes. Trends in Plant Science, 3(5), 195-199.

Shamim, Z., \& Armstrong, S. J. (2020). Using Genome In Situ Hybridization (GISH) to Distinguish the Constituent Genomes of Brassica nigra and B. rapa in the Hybrid B. juncea. In M. Pradillo \& S. Heckmann (Eds.), Plant Meiosis: Methods and Protocols (pp. 69-78). Springer.

Stajič, E., Kiełkowska, A., Murovec, J., \& Bohanec, B. (2019). Deep sequencing analysis of CRISPR/Cas9 induced mutations by two delivery methods in target model genes and the CENH3 region of red cabbage (Brassica oleracea var. Capitata f. Rubra). Plant Cell, Tissue and Organ Culture (PCTOC), 139(2), 227-235.

Stoler, S., Keith, K. C., Curnick, K. E., \& Fitzgerald-Hayes, M. (1995). A mutation in CSE4, an essential gene encoding a novel chromatin-associated protein in yeast, causes chromosome nondisjunction and cell cycle arrest at mitosis. Genes \& Development, 9(5), 573-586.

Talbert, P. B., Masuelli, R., Tyagi, A. P., Comai, L., \& Henikoff, S. (2002). Centromeric localization and adaptive evolution of an Arabidopsis histone H3 variant. The Plant Cell, 14(5), 10531066.

Tek, A. L., Stevenson, W. R., Helgeson, J. P., \& Jiang, J. (2004). Transfer of tuber soft rot and early blight resistances from Solanum brevidens into cultivated potato. TAG. Theoretical and Applied Genetics. Theoretische Und Angewandte Genetik, 109(2), 249-254.

Tek, A. L., Song, J., Macas, J., \& Jiang, J. (2005). Sobo, a recently amplified satellite repeat of potato, and its implications for the origin of tandemly repeated sequences. Genetics, 170(3), 12311238.

Tek, A. L., Kashihara, K., Murata, M., \& Nagaki, K. (2010). Functional centromeres in soybean include two distinct tandem repeats and a retrotransposon. Chromosome Res., 18(3), 337-347.

Tek, A.L. (2013, Eylül). Moleküler sitogenetik yöntemlerle bitki genom analizi. Konya Tarla Bitkileri Kongresi. Konya.

Tek, A. L., Stupar, R. M., \& Nagaki, K. (2015). Modification of centromere structure: A promising approach for haploid line production in plant breeding. Turkish Journal of Agriculture and Forestry, 39(4), 557-562.

Varshney, R. K., \& May, G. D. (2012). Next-generation sequencing technologies: Opportunities and obligations in plant genomics. Briefings in Functional Genomics, 11(1), 1-2.

Vats, S., Kumawat, S., Kumar, V., Patil, G. B., Joshi, T., Sonah, H., Sharma, T. R., \& Deshmukh, R. (2019). Genome editing in plants: Exploration of technological advancements and challenges. Cells, 8(11), 1386.

Wang, G., Zhang, X., \& Jin, W. (2009). An overview of plant centromeres. Journal of Genetics and Genomics, 36(9), 529-537.

Yu, W., Han, F., Gao, Z., Vega, J. M., \& Birchler, J. A. (2007). Construction and behavior of engineered minichromosomes in maize. Proceedings of the National Academy of Sciences, 104(21), 8924-8929.

Yu, W., Yau, Y.-Y., \& Birchler, J. A. (2016). Plant artificial chromosome technology and its potential application in genetic engineering. Plant Biotechnology Journal, 14(5), 1175-1182.

Zhong, C. X., Marshall, J. B., Topp, C., Mroczek, R., Kato, A., Nagaki, K., Birchler, J. A., Jiang, J., \& Dawe, R. K. (2002). Centromeric retroelements and satellites interact with maize kinetochore protein CENH3. The Plant Cell, 14(11), 2825-2836. 